\title{
Performance of four meta-heuristics to solve a forestry production planning problem
}

\author{
Emanuelly Canabrava Magalhães ${ }^{1 *}$, Carlos Alberto Araújo Júnior ${ }^{2}$, Francisco Conesa Roca ${ }^{3}$, Mylla Vyctória \\ Coutinho Sousa ${ }^{4}$
}

\begin{abstract}
The use of artificial intelligence as a tool to aid in the planning of forest production has gained more and more space. Highlighting the metaheuristics, due to the ability to generate optimal solutions for a given optimization problem in a short time, without great computational effort. The present study aims to evaluate the performance of the metaheuristics Genetic Algorithm, Simulated Annealing, Variable Neighborhood Search and Clonal Selection Algorithm applied in a model of regulation of forest production. It was considered a planning horizon of 16 years, in which the model aims to maximize the Net Present Value (NPV), having as restrictions age of cut between 5 and 7 years and minimum and maximum logging demand of 140,000 and 160,000 $\mathrm{m}^{3}$, respectively. Different combinations of configurations were considered for each of the metaheuristics, 30-second processing time and 30 replicates for each configuration, all processing being performed in MeP - Metaheuristics for forest Planning software. The Simulated Annealing metaheuristic obtained the best results when compared to the others, reaching the minimum and maximum demand demanded in all tested configurations, in contrast, the Genetic Algorithm was the one with the worst performance. Thus, the capacity to use metaheuristics as a tool for forest planning is observed.
\end{abstract}

Keywords: Artificial intelligence. Forestry. Forest management. Operational research.

\section{Performance de quatro metaheurísticas para solução de um problema de planejamento da produção florestal}

\begin{abstract}
Resumo
O uso da inteligência artificial como ferramenta de auxílio ao planejamento da produção florestal tem ganhado cada vez mais espaço. Destacando-se as metaheurísticas, em função da capacidade de gerar soluções ótimas para determinado problema de otimização em um curto espaço de tempo, sem grande esforço computacional. Pensando nisso, o presente estudo objetiva avaliar o desempenho das metaheurísticas Algoritmo Genético, Simulated Annealing, Variable Neighbourhood Search e Clonal Selection Algorithm aplicadas em um modelo de regulação da produção florestal. Foi considerado um horizonte de planejamento de 16 anos, no qual o modelo apresenta como objetivo a maximização do Valor Presente Líquido (VPL), tendo como restrições idade de corte entre 5 e 7 anos e demanda mínima e máxima madeireira de 140.000 e $160.000 \mathrm{~m}^{3}$, respectivamente. Considerou-se diferentes combinações de configurações para cada uma das metaheurísticas, tempo de processamento de 30 segundos e 30 repetições para cada configuração, sendo todo o processamento realizado no software MeP - Metaheuristics for Forest Planning. A metaheurística Simulated Annealing obteve os melhores resultados quando comparada as demais, atingindo a demanda mínima e máxima exigida em todas as configurações testadas, em contrapartida, o Algoritmo Genético foi o de pior desempenho. Assim, observa-se a capacidade de uso da metaheurística como ferramenta de planejamento florestal.
\end{abstract}

Palavras-chave: Inteligência Artificial. Silvicultura. Manejo Florestal. Pesquisa Operacional.

\footnotetext{
${ }^{1}$ Universidade Federal de Minas Gerais. Instituto de Ciências Agrárias. Montes Claros, MG. Brasil. https://orcid.org/0000-0002-1240-2766

${ }^{2}$ Universidade Federal de Minas Gerais. Instituto de Ciências Agrárias. Montes Claros, MG. Brasil.

https://orcid.org/0000-0003-0909-8633

${ }^{3}$ Universidad de Huelva. Huelva. España.

https://orcid.org/0000-0002-8722-4263

${ }^{4}$ Universidade Federal de Minas Gerais. Instituto de Ciências Agrárias. Montes Claros, MG. Brasil.

https://orcid.org/0000-0001-6139-1250

*Autor para correspondência: emanuellymagalhaes1@gmail.com
}

Recebido para publicação em 28 de outubro de 2019. Aceito para publicação em 02 de fevereiro de 2020.

e-ISSN: 2447-6218 / ISSN: 2447-6218 / (c) 2009, Universidade Federal de Minas Gerais, Todos os direitos reservados. 


\section{Introduction}

One of the main challenges of the forest sector is to attend to the growing demand for wood from legal sources, which should be done to optimize the production process and regulate the remaining stock over the years (Araújo Júnior, 2012). A regulated forest is subject to management regulations that allow the uniformity of volumetric production. This avoids the lack of wood and provides sustainability to the enterprise (Carvalho et al., 2015).

These issues are related to the long-term planning of forest production (Werneburg, 2015), whose planning horizon is more than sixteen years due to the period of growth and development of the raw material, which creates greater complexity for the process of creating strategic plans. This task is commonly performed with the aid of operational research tools, such as linear programming (PL) and integer linear programming (PLI). However, depending on the desired detail for the solution of the problem, PL and PLI have limitations that result in the impossibility to use or use with high computational effort (Araújo Júnior et al., 2017).

This is due to the fact that there is a need to find a solution composed by a considerable set of binary-type decision variables that relate to each other both in time and space. This makes the definition of forest production plans fall into the category of combinatorial problems.

In this way, different search techniques from artificial intelligence have been constantly applied to determine a suitable solution for such problem. In this aspect, the metaheuristics stand out, which have as advantage to obtain very good answers in a relatively short time. Examples are the work of Gomide and Silva, 2009; Binoti et al., 2017; Araújo Júnior et al., 2017, 2018; Ferreira et al., 2018.

Among the aspects considered when indicating a metaheuristic to solve a problem of forest planning, the time spent to generate a very good solution is of extreme importance. The aim of this study was to evaluate the performance of the Metaheuristic Genetic Algorithm (GA), Clonal Selection Algorithm (CSA), Simulated Annealing (SA) and Variable Neighborhood Research (VNS) to obtain potential solutions considering a short time interval.

\section{Material and methods}

The problem of forest production planning was considered for a total area of 4,210 hectares comprising 120 plots, with ages ranging from 1 to 6 years and irregular distribution of area by age class, under a planning horizon of 16 years.

Silvicultural costs were $\mathrm{R} \$ 4,059.05 \mathrm{ha}^{-1}$ (year 1); $\mathrm{R} \$ 1,627.81 \mathrm{ha}^{-1}$ (year 2); R\$ $757.95 \mathrm{ha}^{-1}$ (year 3); and $\mathrm{R} \$ 88.20 \mathrm{ha}^{-1}$ for the remaining years from the fourth.
Revenues referring to the commercialization of wood were: $\mathrm{R} \$ 20.00 \mathrm{~m}^{-3}$ (less than 3 years old); $\mathrm{R} \$ 30,00 \mathrm{~m}^{-3}$ (4 years old); $\mathrm{R} \$ 40.00 \mathrm{~m}^{-3}$ (5 years old); and, $\mathrm{R} \$ 80.00$ $\mathrm{m}^{-3}$ (ages equal or superior to 6 years).

The mathematical model for integer linear programming aims to maximize the Net Present Value (NPV), including as restrictions the age of cut between 5 and 7 years and the minimum and maximum annual demand for wood of 140,000 $\mathrm{m}^{3}$ and $160,000 \mathrm{~m}^{3}$, respectively.

$\operatorname{Max} G N P V=\sum_{\mathrm{i}=1}^{\mathrm{M}} \sum_{\mathrm{j}=1}^{\mathrm{N}} \mathrm{C}_{\mathrm{ij}} \mathrm{X}_{\mathrm{ij}}$

Subject to

$\sum_{\mathrm{i}=1}^{\mathrm{M}} \sum_{\mathrm{j}=1}^{\mathrm{N}} \mathrm{X}_{\mathrm{ij}}=1$

$\sum_{\mathrm{i}=1}^{\mathrm{M}} \sum_{\mathrm{j}=1}^{\mathrm{N}} \mathrm{V}_{\mathrm{ij}(\mathrm{k})} \mathrm{X}_{\mathrm{ij}} \geq \operatorname{Dmin}_{\mathrm{k}}$

$\sum_{\mathrm{i}=1}^{\mathrm{M}} \sum_{\mathrm{j}=1}^{\mathrm{N}} \mathrm{V}_{\mathrm{ij}(\mathrm{k})} \mathrm{X}_{\mathrm{ij}} \leq \operatorname{Dmax}_{\mathrm{k}}$

$\mathrm{X}_{\mathrm{ij}} \in\{0,1\}$

where: GNPV is the global net present value for all the forest, in reais; Cij is NPV for stand $i$ when assigned the prescription $\mathrm{j}$, in reais; $\mathrm{Xij}$ is the decision variable and represents the proportion area of stand $i$ that will be managed with prescription $\mathrm{j} ; \mathrm{M}$ is the total number of stands; $\mathrm{N}$ is the total number of different prescriptions for each stand; $\operatorname{Vij}(\mathrm{k})$ is the total volume of wood for the stand $i$, when assigned the prescription $j$, in the period k of planning horizon; Dmink and Dmaxk are minimum and maximum wood demand for the period $\mathrm{k}$ of the planning horizon.

Constraint (2) guarantee that all stand area receive one prescription. Constraints (3) and (4) limit the annual harvested volume between a minimum and a maximum values of demand. Finally, constraint (5) impose that there is only one management prescription for each stand.

Thus, the problem of forest planning described is the definition of the sequence of harvest and planting of each of the plots over the period of 16 years. With this, each field can be managed under 81 different prescriptions and in combination with the other 119 remaining fields in order to meet the annual demand for wood. Thus, $120 \mathrm{e} 81$ solutions to the problem are possible, and it is necessary to find the best of them or the best possible ones.

For each metaheuristic, different combinations of its parameters were tested, in order to find the one that best solves the problem within the thirty second processing interval.

For the Genetic Algorithm (GA), the following parameters were considered: with and without elitism; two types of crossing (1 cut-off point and uniform); two types of parent selection for cross (roulette and tournament); and two types of mutation (random gene choice and gene to gene). The initial population size was equal 
to 50 individuals, the mutation rate equal to $1 \%$ and the crossing rate equal to $80 \%$. For CSA, three different values were considered for hypermutation $(\mathrm{H})$, cloning (C), selection (S) and substitution (Sub) rates, being equal to $0.20,0.50$ and 0.80 . Three values for initial population (InP) size were evaluated, being 20, 50 and 80 individuals. In order to test the CSA parameters, it was decided to follow the methodology proposed by Araújo Júnior et al. (2018).

For the Simulated Annealing (SA) was evaluated: three initial temperatures (IT), being $10^{8}, 10^{6}$ and $10^{4}$; three temperature reduction rates $(\alpha)$, being $0.01,0.05$ and 0.10; and three numbers of neighbors evaluated in each iteration (V), with quantities equal to 1,10 and 30 .

In the Variable Neighborhood Search (VNS), two structures were analyzed: structure A with percentages of changes of $1 \%, 2 \%, 3 \%$ and $4 \%$ and structure B with percentages of $10 \%, 20 \%, 30 \%$ and $40 \%$; each structure was executed considering five different amounts of neighbors evaluated (1, 10, 30, 50 and 100).

Data processing considering the different configurations was carried out in the application Metaheuristics for Forest Planning (MeP), developed in the Laboratory of Operational Research and Forest Modeling (LPM) of the Federal University of Minas Gerais.

With the results by the algorithms in each repetition, the amount of viable solutions obtained was counted. After that, the fitness values related to the NPV and the solutions that obeyed the demand for the required wood demand were evaluated.

The entire linear programming model was executed in the Lingo software considering a stop processing time equal to fifteen minutes.

\section{Results and discussion}

The best solutions presented by each algorithm and their respective configurations were: $\mathrm{R} \$$ $31,954,028.00$ for the VNS, with 100 neighbors and structure 1 ; R\$31,872,534.00 for CSA, with initial population size equal to 20 , substitution rate 0.2 , selection rate 0.2 , cloning rate equal to 0.8 , and hypermutation rate equal to $0.2 ; \mathrm{R} \$ 30,782,473.00$ for $\mathrm{SA}$, with initial temperature of $10 \mathrm{e} 8$, temperature decay rate of 0,01 and evaluation of 30 neighbors. The GA did not present any viable solution in all evaluations. The solution obtained by the branch and bound algorithm presented value equal to $\mathrm{R} \$ 31,274,496.00$.

The CSA presented feasible solutions in only three parameter combinations. VNS presented feasible solutions in four of the 10 combinations evaluated and the SA presented feasible solutions in 26 of the 27 combinations tested. The mean of viable replicates for each combination was $72.2 \%$ for SA, $10.8 \%$ for VNS and $4.4 \%$ for CSA.

The viability of the solutions is related to the fact that it is necessary to produce an annual quantity of wood that does not exceed the established minimum and maximum limits. This was observed for the best solutions (Table 1). It is important to note that harvesting a larger total amount of wood (over 16 years) did not reflect higher NPV. This is due to the fact that the model seeks to optimize the financial return rather than the maximization of production. Thus, the importance of sequencing of the harvest is emphasized so that there is a better yield in terms of NPV with lower volume of harvested wood.

These results demonstrate the superiority of SA metaheuristics in relation to the search for viable solutions. Such performance had already been highlighted in other studies, such as those of Ezquerro et al. (2016), in which the authors mention that SA is one of the most cited in the forest literature, and Rodrigues et al. (2004a), where the authors state that SA is one of the metaheuristics that are less affected by changes in their parameters.

The metaheuristics AG is widely applied to solve forestry planning problems (Rodrigues et al., 2004b; Gomide et al., 2009; Silva et al., 2009; Binoti et al., 2014 and Matos, 2017). However, its use has been diminished as new algorithms appear that are more efficient during the search process of solutions. The algorithm was sensitive to the parameter definition, as observed by Gomide et al. (2009).

Another aspect is related to the number of operations that the algorithm needs to perform during the same generation, especially when adopting a larger number of individuals for the initial population. Thus, too much time is spent without evolution of populations to generate better individuals, as discussed by Rodrigues et al. (2004b). The fact that the algorithm found no feasible solution in all cases reveals that it is necessary to evaluate new ways of improving the GA search process as suggested in Gaspar-Cunha et al. (2013).

The CSA and VNS metaheuristics presented better solutions in terms of fitness value than the solutions found by the SA. These algorithms were initially applied to forest problems in the works of Araújo Júnior et al. (2017, 2018) presenting efficacy above that found for the traditional algorithms (SA and AG).

The values of the hypermutation and substitution rates were the same ones found by Araújo et al. (2018). However, the other parameters did not present the same values. This shows the need to define a set of parameters for each situation analyzed, which suggests the use of adaptive mechanisms, so that these values are changed during the execution of the algorithm. 
Magalhães, E. C. et al.

Table 1 - Volume produced annually by the best solutions found

\begin{tabular}{lccccc}
\hline \multirow{2}{*}{ Period } & \multicolumn{5}{c}{ Volume of wood $\left(\mathbf{m}^{3}\right)$} \\
\cline { 2 - 6 } & AG* & CSA & SA & VNS & PLI \\
\hline 1 & - & 142,698 & 146,998 & 142,698 & 140,484 \\
2 & - & 140,065 & 142,086 & 142,581 & 141,675 \\
4 & - & 146,319 & 147,853 & 141,840 & 156,355 \\
5 & - & 140,834 & 159,368 & 151,911 & 152,074 \\
6 & - & 149,847 & 149,718 & 144,807 & 155,084 \\
7 & - & 144,031 & 146,717 & 142,817 & 158,132 \\
8 & - & 145,744 & 152,802 & 140,022 & 140,001 \\
9 & - & 140,562 & 140,041 & 142,686 & 141,386 \\
10 & - & 141,206 & 144,331 & 142,760 & 140,070 \\
11 & - & 140,775 & 142,422 & 140,324 & 144,200 \\
12 & - & 144,692 & 149,017 & 140,029 & 142,836 \\
13 & - & 144,966 & 156,897 & 140,644 & 144,871 \\
14 & - & 140,441 & 141,289 & 142,833 & 142,846 \\
15 & - & 143,707 & 141,128 & 140,250 & 141,286 \\
16 & - & 140,053 & 141,115 & 140,356 & 140,040 \\
\hline Total & - & 146,823 & 141,788 & 140,636 & 140,168 \\
\hline & - & $2,292,763$ & $2,343,570$ & $2,277,194$ & $2,321,508$ \\
\hline
\end{tabular}

The configuration determination of the metaheuristics used is a process of great importance and complexity, mainly because it is dependent on the problem to be solved, so there is no standardization of the configuration for each tool making scientific research in this area necessary.

\section{Conclusion}

The Metaheuristic Genetic Algorithm was unable to generate viable solutions in a short period of time and was not indicated for the problem in question.

The simulated annealing metaheuristic was less affected by the initial configuration of its parameters and this is an important feature when choosing an algorithm to optimize a forest production planning problem. The metaheuristics Clonal Selection Algorithm and Va- riable Neighborhood Search presented the highest values of fitness, although they occur in few repetitions. It is possible to conclude that there is great potential in such algorithms to solve the problem in question.

It can be concluded that for all metaheuristics, it is important to define an initial structure of parameters that guarantee good solutions in a relatively short period of time.

\section{Acknowledgment}

The authors express their thanks to The Minas Gerais State Research Foundation (FAPEMIG) and Brazilian National Council for Scientific and Technological Development $(\mathrm{CNPq})$ for their financial support and to the Federal University of Minas Gerais for their scientific support.

\section{References}

Araújo Júnior, C. A.; Leite, H. G.; Soares, C. P. B.; Binoti, D. H. B.; Souza, A. P.; Santana, A. F; Torre, C. M. M. E. 2017. A multi-agent system for forest transport activity planning. Cerne, 23: 329-337. Doi: http://dx.doi.org/10.1590/01047760201723032335.
Araújo Júnior, C. A.; Mendes, J. B.; Cabacinha, C. D.; Assis, A. L. de; Matos, L. M. A.; Leite, H. G. 2018. Meta-heuristic clonal selection algorithm for optimization of forest planning. Revista Árvore, 41: 1-10. Doi: http://dx.doi.org/10.1590/1806-90882017000600007. 
Performance of four meta-heuristics to solve a forestry production planning problem

Araújo Júnior, C. A. 2012. Simulação multiagentes aplicada ao planejamento da produção florestal sustentável. Viçosa: Universidade Federal de Viçosa. Dissertação.

Binoti, D. H. B.; Binoti, M. L. M. S.; Leite, H. G.; Gleriani, J. M.; Ribeiro, C. A. A. 2014. Inclusão e influência de características espaciais em modelos de regulação florestal. Cerne, 20: 157-164. Doi: http://dx.doi. org/10.1590/S0104-77602014000100019.

Carvalho, K. H. A.; Silva, M. L.; Binoti, D. H. B.; Binoti, M. L. M. S. 2015. Influência da taxa de juros e do preço da madeira em modelos de regulação florestal. Pesquisa Florestal Brasileira, 35: 143-151. Doi: https://doi.org/10.4336/2015.pfb.35.82.554.

Ezquerro, M.; Pardos, M.; Diaz-Balteiro, L. 2016. Operational research techniques used for addressing biodivertity objetives into forest management: an overview. Forests, 7: 229-247. Doi: https://doi. org/10.3390/f7100229.

Ferreira, P. H. B.; Matos, L. M. A.; Assis, A. L.; Cabacinha, C. D.; Araújo Júnior, C. A. 2018. Influência dos parâmetros da metaheurística simulated annealing em um problema de planejamento da produção florestal. Caderno de Ciências Agrárias, 10: 59-67.

Gomide, L. R.; Arce, J. E.; Silva, A. C. L. 2009. Uso do algoritmo genético no planejamento florestal considerando seus operadores de seleção. Cerne, 15: 460-467.
Matos, L. M. A. 2017. Utilização da metaheurística algoritmo genético em um modelo de regulação da produção florestal. Montes Claros: Universidade Federal de Minas Gerais. Dissertação.

Rodrigues, F. L.; Leite, H. G.; Santos, H. N.; Souza, A. L.; Ribeiro, C. A. A.S. 2004a. Metaheurística simulated annealing para solução de problemas de planejamento florestal com restrições de integridade. Revista Árvore, 28: 247-256. Doi: http://dx.doi.org/10.1590/S010067622004000200011

Rodrigues, F. L.; Leite, H. G.; Santos, H. N.; Souza, A. L.; Silva, G. F. 2004b. Metaheurística algoritmo genético para solução de problemas de planejamento florestal com restrições de integridade. Revista Árvore, 28: 233-245. Doi: http://dx.doi.org/10.1590/S0100-67622004000200010.

Silva, G. F.; Piassi, L.C.; Mora, R.; Martins, L.; Teixeira, A. F.; Júnior, A. A. B. 2009. Metaheurística algoritmo genético na solução de modelos de planejamento florestal. Revista Brasileira de Ciências Agrárias, 4: 160-166. Doi: http://dx.doi.org/10.5039/agraria.v4i2a7.

Werneburg, M. A. P. 2015. Planejamento em grandes empresas florestais no Brasil. Diamantina: Universidade Federal do Vale do Jequitinhonha e Mucuri. Dissertação. 